11 Singh S, Wann LS, Schuchard GH, et al. Right ventricular and right atrial collapse in patients with cardiac tamponade: a combined echocardiographic and hemodynamic study. Circulation 1984;70:966-71

12 Engel PJ, Hon H, Fowler NO, Plummer S Echocardiographic study of right ventricular wall motion in cardiac tamponade. Am 7 Cardiol 1982;50:1018-21.

13 Feinstein AR. Clinical epidimiology: the architecture of clinical research. Philadelphia: WB Saunders, 1985.

14 Armitage P, Berry G. Statistical methods in medical research. 2nd ed. Blackwell Scientific Publications, 1987.

15 Cox DR. Regression models and life tables. $\mathcal{F} R$ Stat Soc [B] 1972;34:187-220.

16 Kline IK. Cardiac lymphatic involvement by metastatic tumor. Cancer 1972;29:799-808.

17 Quraishi MA, Costanzi J, Hokanson J. The natural history of lung cancer with pericardial metastases. Cancer 1983;51:740-2.

18 Okamoto H, Shinkai T, Yamakido M, Saijo N. Cardiac tamponade caused by primary lung cancer and the management of pericardial effusion. Cancer 1993;71: 93-8.

19 Park JS, Rentschler R, Wilbur D. Surgical management of pericardial effusion in patients with malignancies. Cancer 1991;67:76-80.

20 Zipf RE, Johnston WW. The role of cytology in the evalua tion of pericardial effusions. Chest 1972;62:593-6.

21 Yazdi HM, Hajdu SI, Melamed MR. Cytopathology of pericardial effusions. Acta Cytol 1980;24:401-12.

22 Vaitkus PT, Herrmann HC, LeWinter MM. Treatment of malignant pericardial effusion. $\mathcal{f} A M A$ 1994;272: $59-64$
23 Wong B, Murphy J, Change CJ, et al. The risk of pericardiocentesis. Am $\mathcal{F}$ Cardiol 1979;44:1110-4.

24 Krikorian JG, Hancock EW. Pericardiocentesis. $\mathrm{Am} \mathcal{f} \mathrm{Med}$ 1978;65:808-14.

25 Davis S, Sharma SM, Blumberg ED, Kim CS Intrapericardial tetracycline for the management of cardiac tamponade secondary to malignant pericardial effusion. N Engl F Med 1978;299:1113-4.

26 Hawkins JW, Vacek JL. What constitutes definitive therapy of malignant pericardial effusion? "Medical" versus surgical treatment. Am Heart $₹$ 1989;118:428-32.

27 Ziskind AA, Pearce AC, Lemmon CC, et al. Percutaneous balloon pericardiotomy for the treatment of cardiac tamballoon pericardiotomy for the treatment of cardiac tamponade and large pericardial effusions: description of Cardiol 1993;21:1-5.

28 Sugimoto JT, Little AG, Ferguson MK. Pericardial window: mechanism of efficacy. Ann Thorac Surg 1990; dow: mech

29 Shepherd FA, Morgan C, Evans WK, et al. Medical management of malignant pericardial effusion by tetracycline sclerosis. Am F Cardiol 1987;60:1 161-6.

30 Palacios IF, Tuzcu EM, Ziskind AA, et al. Percutaneous balloon pericardial window for patients with malignant pericardial effusion and tamponade. Cathet Cardiovas Diagn 1991;22:244-9.

31 Chow WH, Chow TC, Cheung KL. Nonsurgical creation of a pericardial window using the Inoue balloon catheter. Am Heart f 1992;124:1100-2.

32 Jackson G, Keane D, Mishra B. Percutaneous balloon pericardiotomy in the management of recurrent malignan pericardial effusions. Br Heart $\mathcal{f}$ 1992;68:613-5.

\title{
VIEWS FROM THE PAST
}

\section{Cardiac museum specimens in London}

This work was funded by a modest grant from the British Heart

Foundation. The catalogue (Cardiac Museum Specimens in London) can be obtained either in printed format or as a $3 \frac{1}{2}$ inch floppy disc (IBM Compatible WordPerfect $5 \cdot 1$ ) at a cost of $£ 10$ from: Professor RH Anderson, Department

of Paediatrics, National Heart \& Lung Institute, Dovehouse Street, London SW3 6LY.
Mounted museum specimens have been used in medical teaching for over 200 years. Despite modern advances in technology and the development of more convenient and more sophisticated audiovisual teaching facilities, there is still an important role for this form of presentation-especially in cardiology, where the interpretation of modern diagnostic imaging procedures requires a high degree of familiarity with the anatomy of the heart and of the structural changes found in congenital malformations and acquired pathological conditions.

The ideal museum would contain examples of all known abnormalities and would be situated in the immediate vicinity of the place of work. This ideal does not exist. A workable alternative would be to combine, in a single catalogue, the material contained in all the museums within a finite area, so that students, teachers, research workers, and authors can know what specimens are available for study and where they can be found.

It was with this end in view that I set out on my voyages of discovery around London. My equipment consisted of a pen, a pad of paper, and my senior citizen's travel pass. There were no committee meetings, conferences, administrative procedures, or ethical debates, and the project was accomplished without the aid of computers or statistical analysis. There was, however, a lot of goodwill and unstinted cooperation from the various curators, professors, and museum technicians in all of the 17 institutions that I visited.

I had a wonderful time. I went to parts of London I had never been to before, and I viewed over 2000 pots containing examples of every conceivable form of heart disease. Rarities became commonplace after seeing seven cases of paradoxical embolus, 10 myocardial gummas, 13 "carcinoid hearts", 21 aneurysms of the sinuses of Valsalva, 40 atrial myxomas, and numerous other oddities. I saw historical treasures dating back to Napoleonic times and also many conditions that are rarely, if ever, seen in the United Kingdom. Some of the museums were themselves fascinating museum pieces especially those at $\mathrm{St}$ Bartholomew's Hospital, the Royal London Hospital, Guy's Hospital, and the Royal College of Surgeons. Sadly, some of the other collections were rather neglected.

The outcome of these visits was a listing (entitled Cardiac Museum Specimens in London) of 2188 specimens, arranged by institution and also by a comprehensive index embracing both the anatomical structures and the various types of disease processes. There is also a list of who to get in touch with at the various institutions, together with addresses, telephone numbers and the nearest Underground station.

I hope someone out there will find it useful. LEON M GERLIS Honorary Senior Lecturer, National Heart \& Lung Institute, Honorary Consultant Cardiac Pathologist, Royal Brompton Hospital 